\title{
Constraints Related to the Application of the REDD+ Mechanism in a Context of Community Forest Management: Cameroonian Experience as a Congo Basin Country Cases
}

\author{
Ghislain Tikeng Agoum ${ }^{1 *}$, Maurice Tsalefac ${ }^{2}$ \\ ${ }^{1}$ PhD Student, Department of Geography, Planning-Environment, University of Dschang, Dschang, Cameroon \\ ${ }^{2}$ Professor, Department of Geography, Planning-Environment, University of Dschang, Dschang, Cameroon
}

\begin{abstract}
DOI: $10.36348 /$ sjhss.2020.v05i04.008
| Received: 26.03.2020 | Accepted: 02.04.2020 | Published: 30.04.2020
\end{abstract}

*Corresponding author: Ghislain Tikeng Agoum

\section{Abstract}

In order to implement REDD+ for the benefit of forest populations, this article studies the potentialities of the management system of the Covimof community forest (Molombo, Okékat and Faékélé Village Community) located in the region of Central Cameroon, part of the Congo Basin. It relates the REDD+ implementation requirements as defined by the international format (reference scenario, non-additionality, leakage and non-permanence) and governance elements in terms of community forestry in order to identify management constraints for REDD+ implementation in a community forestry context. Based on the development of a socioeconomic, political and institutional framework capable of regulating the implementation of this mechanism, the barriers to REDD+ will be highlighted. Based on field surveys and interviews with stakeholders, the main problems of community forestry management have been elucidated. The results show that REDD+ will face a number of problems including benefit sharing, communication between stakeholders, and land tenure.

Keywords: Community forestry, REDD+, management system, mitigation.

Copyright @ 2020: This is an open-access article distributed under the terms of the Creative Commons Attribution license which permits unrestricted use, distribution, and reproduction in any medium for non-commercial use (NonCommercial, or CC-BY-NC) provided the original author and source are credited.

\section{INTRODUCTION}

The mitigation of climate change through forests is thus the responsibility of rural communities. "Current international discussions on REDD perhaps seem to focus more on indigenous peoples than any other mitigation policy tool considered under the UNFCCC in the past UN-IAS, 2009. Given the importance of the contribution of the forest sector in developing countries, a significant number of observers have taken the initiative to propose several measures that could significantly reduce the rate of deforestation. Since 2005 in Montreal (COP 11), Papua New Guinea and Costa Rica have proposed to integrate tropical forests into the fight against climate change, so that funding can be devoted to the fight against deforestation. Hence RED (Reducing Emissions from Deforestation). Well received at COP 13 in Bali in 2007, the coalition helped to implement the Bali Action Plan. It creates a new framework for concerted action on adaptation, mitigation, technology transfer and financing. In this sense, the countries of the Congo Basin through the Comifac (Central African Forest Commission) have shown interest in linking deforestation. The reduction plan becomes REDD (Reducing Emissions from Deforestation and Degradation). The REDD mechanism thus claims to bring to these populations an improvement in living conditions through the fight against the degradation and deforestation of forest ecosystems. In 2009, Copenhagen is promoting the broadening of the scope of REDD with the inclusion of SFM, conservation and improvement of carbon stocks. REDD becomes REDD+. Henceforth, the implementation of REDD+ by partner countries is conditioned by the development of national country strategies (R-PIN and R-PP). Since the adoption of the Warsaw framework, debates have focused on the construction of the national REDD+ strategy.

In Cameroon, the issue of REDD+ development had initially revolved around the organization of the multi-stakeholder forum and stakeholder awareness raising with capacity building as a first variant. Since 2018, REDD+ activities and the institutional and socioeconomic framework are set out in the REDD+ action plan. In this context, NGOs and civil society are trying to understand MRV actions by 
accessing funds via partner countries that encourage private initiatives related to the feasibility of REDD+. These initiatives, which oblige States to make an effort to govern forest areas while allowing REDD+ to emerge from the consensus debate, may eventually be extended to community forestry. Addressing community forest management issues then becomes a condition for sustainable community engagement in REDD+. In this context, the Covimof forest is now turned to this new forest management challenge focused on climate change mitigation. Will it be possible for Covimof to comply with management constraints in terms of REDD+ implementation in a community forest management context?

Indeed, the populations affiliated to the CIG (common initiative group) Covimof in the Mbalmayo district are facing methodological and technical obstacles to operation required by REDD+. Our analysis claims to contribute to the identification of management constraints for the implementation of the future REDD+ mechanism (reference scenario, nonadditionality, leakage and non-permanence) with a view to developing a socioeconomic, political and institutional framework capable of regulating REDD+ implementation. To achieve this objective, we hypothesized that the management constraints related to the implementation of REDD+ can be identified at the level of political, institutional and socioeconomic factors that influence the way the community forest operates and consequently the quality of life of the Covimof populations Cig. To carry out this study, we have articulated the work at 5 levels. First, the technical potential to establish a reference scenario. The field data made it possible to identify the socioeconomic aspects that can influence the application of REDD+. Then, the analysis of the strategies of the actors in the functioning of the community forest as a source of nonadditionality in a second step led to a mixed finding. That of policies and incentives that legitimize access to the resource and are a cause of leakage. A priori, the various forms of institutional control and related conflicts can inhibit the permanence of REDD+ activities. Finally, the reflection proposes mitigating the political, social and economic weaknesses that the Durban Platform should take into account for strengthened action, subject to respect for the sovereignty of fragile states such as Cameroon.

\section{Spatial Context and Study Methodologies Spatial Context}

This research work was conducted in Cameroon, a central African country covered in the south by the Congo Basin forest, the second largest forest country after the Democratic Republic of Congo. The Cameroonian forest represents an important part of the national economy and provides livelihoods to the local population whose activities are mainly based on agriculture and assisted forestry.
This research work was conducted in Cameroon, a Central African country covered to the south by the Congo Basin forest, and the second largest forest country after the Democratic Republic of Congo. The Cameroonian forest represents an important part of the national economy and provides livelihoods to the local population whose activities are mainly based on agriculture and assisted forestry. Indeed, the Covimof forest area was chosen as a study unit because, on the one hand, the climate change mitigation currently being considered at the level of international negotiations takes note of the need to establish safeguard measures for the application of REDD+ to community benefits. On the other hand, among the 16 "hotspots" of degradation and deforestation identified in Central Africa in 1997 by the TREES project, 4 are located in Cameroon. The second is the vast region bounded by the four cities of the capital Yaoundé, Mbalmayo, Ebolowa, and Kribi, which is in the process of being cleared for conversion to agriculture [1]. The Covimof Cig community forest $\mathrm{N}^{\circ} 22$ reserved under $\mathrm{N}^{\circ} 0453$ / L / MINEF / DF/ SDIAF/ SA of 17 February 1999 is located in the Congo Basin. Our study takes place in the district of Mbalmayo. It is a forest located between $3^{\circ} 27^{\prime} 53^{\prime \prime}$ and $3^{\circ} 32^{\prime} 53^{\prime \prime}$ North latitude and between $11^{\circ} 32^{\prime} 30^{\prime \prime}$ and $11^{\circ} 37^{\prime} 2^{\prime \prime}$ East longitude. It is located in Nyong and So'o, one of the nine Departments of Central Cameroon. Thus, the Covimof Cig community forest located $15 \mathrm{~km}$ from Mbalmayo can be the subject of special attention. The higher loss of forest cover in the Npfe (Non-Permanent Forest Estate) than in the Pfe (Permanent Forest Estate) indicates that zoning is generally respected. But it is also suggested that a strategy to reduce emissions needs to pay particular attention to Npfe lands threatened by massive conversion. Indeed, the Covimof Cig community forest located $15 \mathrm{~km}$ from Mbalmayo can be the subject of special attention. Due not only to the loss of forest cover, higher on the Npfe than on the Pfe indicates that zoning is generally respected. But it is also suggested that a strategy to reduce emissions should pay particular attention to Npfe lands threatened by massive conversion.

\section{METHODOLOGY OF THE STUDY}

The CIG Covimof community forest consists of 8 villages. We placed proportionally a quantity of questionnaires (10 per village) inside each riverside village. The surveys were focused only on the active population that owns cultivable or fallow plots within the community space. According to the statistics from the new simple management plan, the sampling frame consists of those aged 30 years and over of a total of 397 people. 61 out of 80 people in this active population were surveyed. The study used map data from 1992 onwards. The REDD+ theme is evolving. It will be more focused from the Durban decision COP 17, 2011 to the Warsaw decision COP, 2015. The document relating to Covimof via its simple management plan concerns the years before 1994, i.e. 
before the creation of the community forest, and from 1994 until today (2018, year of formulation of the national REDD+ strategy). It was interesting to see the socioeconomic stakes that made it possible to revisit different reconfigurations of the spatial dynamics around community forestry. The primary data collected focused on community resource management: ownership systems (collective and individual), community spaces as sources of conflicts, means of substances or as forest rent sharing, management and rural development policies focused on the involvement and participation of forest communities. The evolution of international negotiations on climate change has made it possible to identify the difficulties of implementing REDD+ pilot projects in forest countries.

Ultimately, REDD+ is currently under discussion within the United Nations Framework Convention on Climate Change. The last exchanges took place in early December 2011. Currently, the methodological arsenal on the implementation of the REDD mechanism is in progress and calls for exchanges taking into account the national and sociocultural circumstances of each forest country. However, the methodological tools have been complemented by the expert judgment method whose purpose is to assess current and future vulnerability in terms of REDD+ implementation within Covimof and to develop implementation strategies with regard to the management elements of a Community Forestry which will be the basis for the characterization of risks (current and future) and the assessment of the impact of these risks. The management elements that serve as a basis for analyzing the risks of non-application of REDD+ is presented in the form of a matrix of impacts of the risks of non-application of REDD+ called "REDD+ risks" in the context of this work.

Table-1: Impact matrix of REDD+ risks

\begin{tabular}{|c|c|c|c|}
\hline \multicolumn{4}{|l|}{ REDD+ RISK IMPACT MATRIX } \\
\hline \multirow[t]{2}{*}{ Elements of FC exposure to REDD+ risks } & \multicolumn{3}{|c|}{ IMPACTS OF REDD+ RISKS } \\
\hline & $\begin{array}{l}\text { CURRENT } \\
\text { RISK }\end{array}$ & $\begin{array}{l}\text { FUTURE } \\
\text { RISK }\end{array}$ & $\begin{array}{l}\text { RESPONSE } \\
\text { STRATEGIES } \\
\text { (MITIGATION) }\end{array}$ \\
\hline $\begin{array}{l}\text { Reference Scenario: } \\
\text { Forest carbon stock, state of road infrastructure, participation, } \\
\text { transparency, consistency, adjustment factor }\end{array}$ & & & \\
\hline $\begin{array}{l}\text { Non-additionality: } \\
\text { Stakeholders, relationships between them; benefit sharing, } \\
\text { agropastoral practices }\end{array}$ & & & \\
\hline $\begin{array}{l}\text { Leaks: } \\
\text { Ownership systems, public policies and incentives for access to the } \\
\text { resource }\end{array}$ & & & \\
\hline $\begin{array}{l}\text { Non Permanence: } \\
\text { Control of forest activities, conflict management, Co-benefits (poverty } \\
\text { reduction, alternative livelihoods, biodiversity, protection and } \\
\text { enhancement of rights. }\end{array}$ & & & \\
\hline
\end{tabular}

Source: Authors, 2018

\section{RESULTS}

\section{Technical constraints related to the determination of the reference scenario}

Any exercise to estimate $\mathrm{BaU}$ emissions (base as usual) requires an understanding of the complexity of the causes and trajectories of deforestation in the area of interest. Ecosystem evolution follows complex trajectories and is driven by many interacting factors [2]. On this basis, a nested approach is allowed and gives the possibility to start applying REDD at the project scale. Indeed, the challenge in determining a reference scenario lies in its typology. Cameroon through its R-PP in Component 3 proposed a historical RL [3] coupled with development adjustment factors [4] to take into account national circumstances [5]. Nevertheless, given the different presentations of the forest resource by the communities, the concern may first of all lie in the determination and updating of the causes of deforestation by the communities themselves. The only major asset here is peasant environmental awareness. 


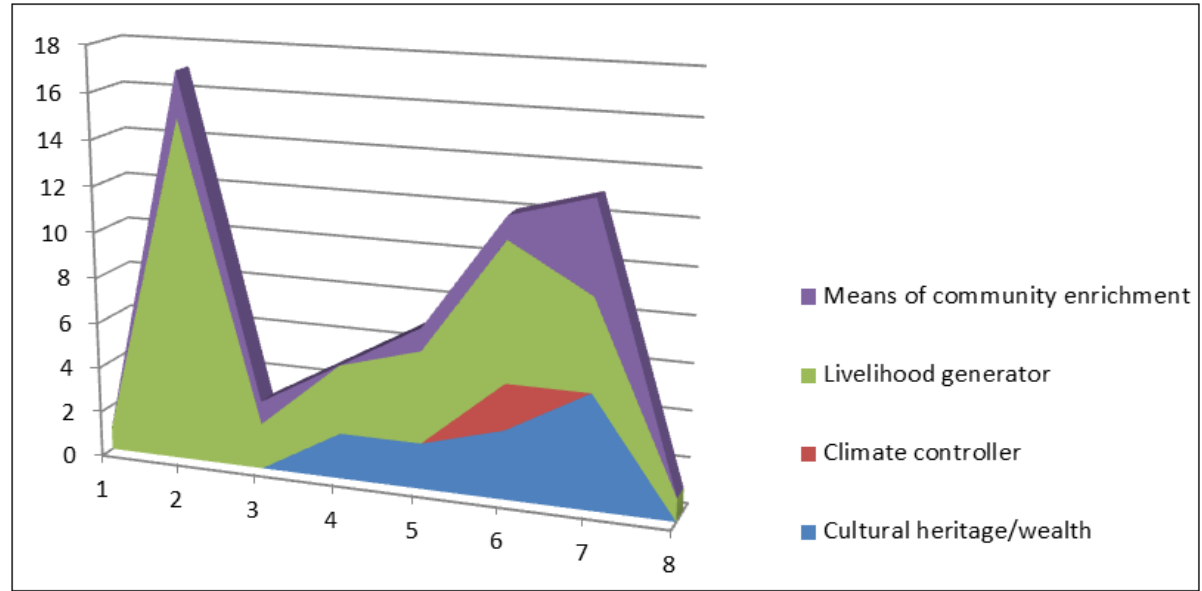

Fig-1: Representation of the forest resource by the Covimof community Source: Field survey data, 2018

In addition, the IPCC interpretation of satellite imagery, which must be based on the reference period [6], with a methodology of having at least three soil maps for a period of 10 to 15 years before the start of the project, is a difficulty in that the acquisition of satellite maps does not always coincide with the required reference period. In addition, the IPCC guidelines do not specify at what elevation the maps should be taken in order to make the interpretation as convincing as possible, so that changes in forest cover can be easily interpreted.

Stakeholders, strategies, socio-economic and environmental issues as a risk of non-additionality

With the proliferation of stakeholders (REM, RIGC, Minader, Minfof, CED, etc.) involved in a management system such as Covimof, the risks of not adding up if REDD+ is applied are obvious. The data collected in the field made it possible to identify possible threats supposedly delaying the assimilation of new REDD+ practices. Indeed, stakeholders are legal or natural persons who act on the forest resource according to divergent or common interests and stakes. Their competitiveness produced on the space of clichés that are fairly representative of the types of relationships that exist between them. In front of the communities, which are the closest stakeholder to the area in terms of identity richness, historical facilities and the least equipped in terms of organisational capacity, the other stakeholders who are the most favoured in terms of financial and technical resources come in second place. Some for economic interests and others for individual or purely economic interests. The first uncertain and timid relationship is between the management committee and the population of Covimof. The latter has no relationship with the Minfof, the Minepded and the economic partners.

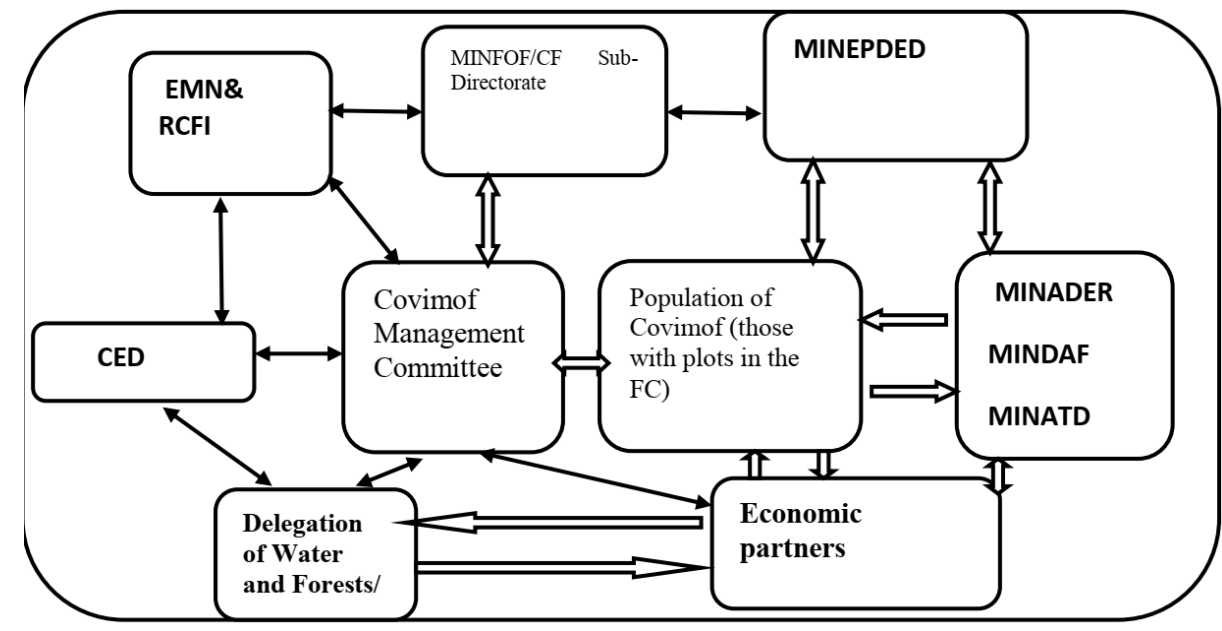

Fig-2: Relationship diagram between different stakeholders involved in the COVIMOF Source: Field survey data, (2018)

Also, the EMN [7] and the RCFI [8] have been in contact with the populations during projects or field investigations. This type of relationship was spontaneous. The Délégation Départementale des Forêts is the intermediary of the various stakeholders. This foresees a certain relationship between the CED (Centre for Environment and Development), the management committee, the Minfof (Ministry of Forests and Fauna) 
and the Departmental Delegation of Forests. These types of relationships predispose the different categories of stakeholders to easy access to the resource and the development of use mechanisms. Faced with the distortions and constraints of the Covimof management (Covimof's legal model, extension of inheritance rights and restrictive administrative procedures for forest exploitation), the area is perceived as a "screen space". The different behaviours of the actors are exposed there. There is a crossbreeding of land use. In fact, administrative management of the area by tracing leons and traditional management by respecting the boundaries of individual plots are simultaneously carried out. The different species to be exploited, combined with fallow land, plantations, bare areas and less exploited areas (forest cover in good condition) make it possible to understand the dichotomy that exists between the transferred management right and the management right itself. In this context, there is a high risk of resilience in changing practices. This vulnerability (current and future) is more evident at the level of the system of public policies and measures that maintain the behaviour of stakeholders upstream.
Appropriation systems, public policies and measures for ecosystem management management, stakeholder behaviour and risk of leakage generation

REDD+ via the carbon market has caused a detonation in terms of forest land rights. The establishment of carbon ownership requires a clarification of customary rights that highlights the extent of the owner's powers. In Covimof's case, the majority state ownership system obeys the laws and regulations governing community forestry in Cameroon and does not clearly define the prospects of a future plot holder acquiring carbon credits. The risk here is future because the process will ultimately depend on the definition of the forest. Indeed, it is difficult in terms of community forestry in Cameroon to accommodate REDD+ under such conditions. The management powers transferred to the communities do not give them the fullness to carry out substantive transactions on the forest resource.

Table-2: Categorization and scope of management powers conferred by the Community Forest Management Convention

\begin{tabular}{|l|l|l|}
\hline POWERS & $\begin{array}{l}\text { OWNERSHIP RIGHT } \\
\text { TRANSFERS }\end{array}$ & EFFECTS \\
\hline $\begin{array}{l}\text { Management by management } \\
\text { agreement or simple management } \\
\text { plan }\end{array}$ & $\begin{array}{l}\text { Temporary right of ownership, in } \\
\text { this case usufruct and enjoyment }\end{array}$ & $\begin{array}{l}\text { No possibility of transaction (No right to transfer the } \\
\text { land) } \\
\text {-Operations by control room }\end{array}$ \\
\hline $\begin{array}{l}\text { Fruit collection, transaction } \\
\text { possibilities }\end{array}$ & Right of usufruct and right of use & $\begin{array}{l}\text { Enjoyment of the fruits received from the sale of } \\
\text { Timber Forest Products and Non-Timber Forest } \\
\text { Products. }\end{array}$ \\
\hline Customary, cultural power & $\begin{array}{l}\text { Axe law, Inheritance law, } \\
\text { Inheritance law }\end{array}$ & $\begin{array}{l}\text { Materialization and traditional defenses of the village } \\
\text { customary space. Preservation of family assets }\end{array}$ \\
\hline
\end{tabular}

Source: Field survey data, (2018)

The management agreement granted to the populations gives them a limited power in the management and exploitation. The power to use and collect the fruits of this power without abusing it is in competition with customary power. The latter highlights the triple cultural, customary and family dimension of the Covimof forest area. In a context of local development, these same rural people formulate survival strategies that do not often coincide with the objectives of forest land management. This situation presages an important risk in the marketing and sharing of carbon credits. Finally, in the face of a system of state appropriation, the classic land management schemes, which preciously obeys the "felling-burningcropping" system, are being watermarked by a system of state appropriation. Depending on the means of intervention of communities, pockets of deforestation, sheltered from any reforestation initiative, follow.

Table-3: Means of community intervention in the Covimof forest

\begin{tabular}{|l|l|l|l|l|l|}
\hline Village & $\begin{array}{l}\text { Small-scale } \\
\text { shifting cultivation }\end{array}$ & $\begin{array}{l}\text { Small-scale food } \\
\text { agriculture }\end{array}$ & $\begin{array}{l}\text { Harvesting firewood } \\
\text { for self-consumption }\end{array}$ & $\begin{array}{l}\text { Harvesting fuelwood } \\
\text { for urban marketing }\end{array}$ & $\begin{array}{l}\text { Reforestation of } \\
\text { degraded/deforested } \\
\text { areas }\end{array}$ \\
\hline Akak & 1 & 1 & 0 & 0 & 0 \\
\hline Ayos & 17 & 17 & 4 & 0 & 0 \\
\hline Akyda1 & 3 & 3 & 1 & 1 & 0 \\
\hline Akyda2 & 6 & 2 & 0 & 3 & 0 \\
\hline Fakélé1 & 7 & 6 & 1 & 0 & 0 \\
\hline Fakélé2 & 12 & 6 & 9 & 0 & 1 \\
\hline Melo & 13 & 11 & 0 & 1 & 2 \\
\hline Okekat & 1 & 11 & 17 & 0 & 0 \\
\hline Total & 60 & 1 & 56 & 5 & 5 \\
\hline
\end{tabular}

Source: Survey results (2018) 
Faced with these different means of intervention, hybrid mechanisms, both administrative and customary, can regulate access to the resource so as to promote the permanence of REDD+ projects in a community forestry context.

Administrative and customary mechanisms for
regulating forms of intervention in Covimof: basis
for reflection on the risks of non-permanence of
REDD+ projects
Whether customary or state-based, the perspective would be that control mechanisms could keep future REDD+ activities intact. Indeed, Covimof has long been the site of forestry and agricultural activities. It is an agro-forestry strip that has been the center of interest for several logging companies. Today, the state of the resource highlights the great concern about community reforestation actions. In spite of the control and monitoring strategies in place, conflict resolution methods do not always produce satisfaction. Between modern control and village monitoring, a language of the deaf is emerging. According to the manual of procedures for the creation of community forests, control is the responsibility of the administration and monitoring is the responsibility of the community.

\section{State Control}

On the one hand, control over logging is quite remote and devoid of interest, because Community Forest $(\mathrm{CF})$ is managed for and by communities. In this respect, it is interesting to recall that the State is also an actor, which has its own interests to defend and where the control system is a function of the means of locomotion. The low means allocated to the regional brigades, departmental delegations are very low. The lack of motivation with the abolition of risk premiums has led to a virtual absence of forest administration agents in the field. On the other hand, the almost nonexistent control of agricultural activities fuels land pressure. This race to prepare land inheritance calls for the development of plots of land. Most of the populations of Covimof are farmers and wish to pass on agricultural know-how to their future generations. Farming practices are mostly made up of felling wooded areas, bush fires and fallow land. These farming habits are not subject to any control by the forest administration. The same is true of the decentralized services of the Minader (Ministry of Agriculture and Rural Development), which can be credited with having aroused among the people of Covimof a disproportionate desire to turn to agriculture in forest areas, through the creation of agricultural CIGs. Allowing the residents of a forest to exploit it for agricultural purposes, in order to achieve food security at the national level, has led to neglecting the forms of control of agricultural activities that may be necessary to promote the conservation management of forest ecosystems.

\section{Community Surveillance}

For forestry activities, each village is composed of a delegated supervisor in charge of the control of its area. Within each zone, monitoring may be carried out by any member adhering to the Covimof and sharing the same opinions regarding the concept of community forestry. Those who strongly reject the new management model constitute themselves individual supervisors or are deprived of their own plot of land and therefore operate on the fringe of traditional monitoring without a lack of equipment. Not only do the large distances separate the plots that make up the Covimof. But the increase in collective and individual activities that take place there make surveillance a real Chinese headache. On the one hand, the noise of a power saw at a reasonable distance can be detected by hearing and can be determined by the amount of decibels released into the atmosphere. On the other hand, in addition to sound recognition, some patrols are organized periodically, irregularly and in most cases allow to discover actions that are already past or even flagrant. However, the members of Covimof activate without protective equipment (helmet, boots, individual compasses, etc.) or means of communication, subject to a guarantee of network coverage.

With regard to agro-pastoral activities, the constraints on the monitoring of agricultural and forestry activities are of a complementary nature. The first of the obstacles is the resistance and hostility of the population to community-based activities. That is to say, the very perception of the management of a community space. The second is the lack of communication between the communities due to the distances separating them from the community decision-making centres (Faekélé 2) administrative (Mbalmayo water delegation). The third is the total indifference to the existence of the Covimof Cig, which is basically due to the inefficiency of the participation and involvement process. The fourth is the absence of social and economic works and the inequitable sharing of benefits that pushes the population to take an individual interest in the plots of crops.

\section{Response strategies: REDD+ risk management}

The starting point for REDD+ implementation is the construction of national REDD + policies with regard to the REDD+ standards according to the UNFCCC. Then, an important awareness, information and communication strategy must be implemented in order to establish transparency, coherence and participation links both for the construction of a reference scenario and for the management of nonadditionality risks. 


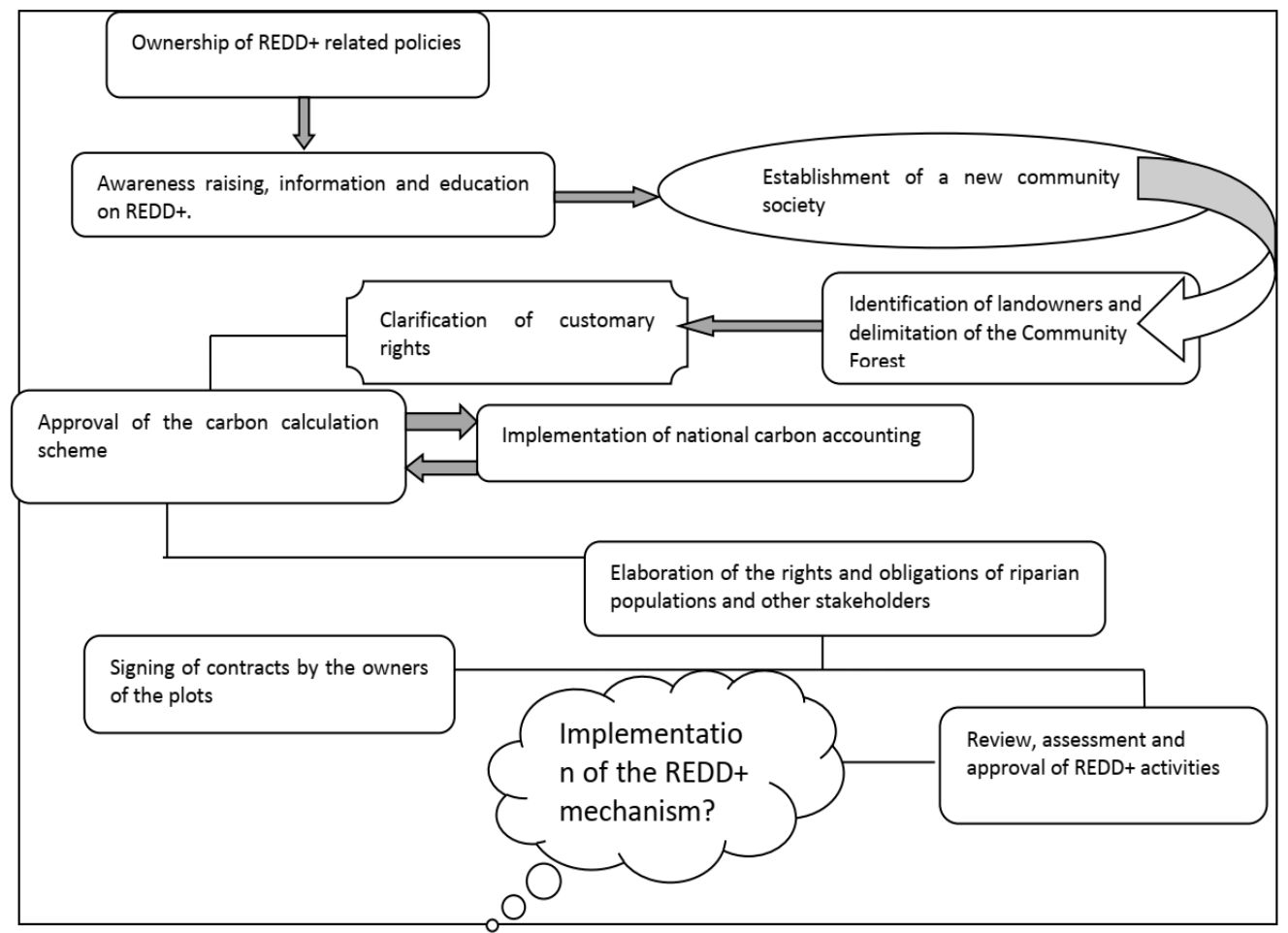

Fig-3: Structural scheme test prior to the implementation of REDD+ activities

Source: Agoum, 2019

Indeed, these indicators should mainly support the achievement of the SDOs (Sustainable Development Objective). Together with the Minader, Minepat is well positioned for the approval of REDD+ programs and projects in compliance with the Rural Development Strategy Statement. In addition, the National Observatory on Climate Change (ONAC), created in 2009 , will focus on the realization and monitoring of environmental and social impacts related to the implementation of REDD+. It will also have to participate in the implementation of a legal framework. However, REDD+ risks will be more amplified if the vulnerability of indigenous peoples to the effects of climate change is largely determined by the extent to which all rights are recognized and guaranteed [9]. To this end, we can safely state that the land tenure issue; directly related to the issue of the definition of the forest is a crucial component of REDD+ policies.

Table-4: Matrix of impacts of REDD+ risks

\begin{tabular}{|c|c|c|c|}
\hline \multirow{2}{*}{$\begin{array}{l}\text { Elements of FC exposure to } \\
\text { REDD+ risks }\end{array}$} & \multicolumn{3}{|c|}{ IMPACTS OF REDD+ RISKS } \\
\hline & CURRENT RISK & FUTURE RISK & RESPONSE STRATEGIES (MITIGATION) \\
\hline $\begin{array}{l}\text { Reference Scenario : } \\
\text { Forest carbon stock, state of road } \\
\text { infrastructure, participation, } \\
\text { transparency, consistency, } \\
\text { adjustment factor }\end{array}$ & $\begin{array}{l}\text { Development of } \\
\text { road infrastructure, } \\
\text { creation of markets, } \\
\text { population growth }\end{array}$ & $\begin{array}{l}\text { Decrease in forest } \\
\text { carbon stock, increase } \\
\text { in demand for wood } \\
\text { energy and lumber }\end{array}$ & $\begin{array}{l}\text { - The Ministry of Economy and Planning as the } \\
\text { first actor in the appropriation of REDD+ policies. } \\
\text {-Mastery of the forest carbon stock by updating } \\
\text { national and sub-national forest inventories } \\
\text { - Awareness, Information and Education on REDD }\end{array}$ \\
\hline $\begin{array}{l}\text { Non-additionality : } \\
\text { Stakeholders, relationships } \\
\text { between them; benefit sharing, } \\
\text { agropastoral practices }\end{array}$ & $\begin{array}{l}\text { Lack of awareness, } \\
\text { information and } \\
\text { prior consent of the } \\
\text { population }\end{array}$ & $\begin{array}{l}\text { Preservation of } \\
\text { degrading practices } \\
\text { Creation of agricultural } \\
\text { CIGs, Development of } \\
\text { agricultural plantations. }\end{array}$ & $\begin{array}{l}\text {-Constitution of a new community society } \\
\text {-Identification of landowners and delimitation of } \\
\text { the Community Forest, Approval of the scheme for } \\
\text { calculating carbon credits, Elaboration of the rights } \\
\text { and obligations of the riparian populations and } \\
\text { other stakeholders. }\end{array}$ \\
\hline $\begin{array}{l}\text { Leaks: } \\
\text { Ownership systems, public } \\
\text { policies and incentives for access } \\
\text { to the resource }\end{array}$ & $\begin{array}{l}\text { Reinforcing the } \\
\text { Displacement of } \\
\text { Labour in Search of } \\
\text { Land Capital } \\
\end{array}$ & $\begin{array}{l}\text { Agricultural activities, } \\
\text { competition in food } \\
\text { markets, transfer of } \\
\text { land. }\end{array}$ & $\begin{array}{l}\text { Restructuring of forest and non-forest sector } \\
\text { policies. Linking to REDD+ activities. } \\
\text { Clarification of customary rights }\end{array}$ \\
\hline $\begin{array}{l}\text { Non Permanence : } \\
\text { Control of forest activities, conflict } \\
\text { management, Co-benefits (poverty } \\
\text { reduction, alternative livelihoods, } \\
\text { biodiversity, protection and } \\
\text { enhancement of rights. }\end{array}$ & $\begin{array}{l}\text { Illegal logging } \\
\text { Lack of benefit } \\
\text { sharing, conflicts, } \\
\text { bushfires }\end{array}$ & $\begin{array}{l}\text { Illegal trade in timber } \\
\text { and wood energy, timid } \\
\text { forest certification, }\end{array}$ & $\begin{array}{l}\text { Signing of contracts between plot owners and } \\
\text { structures in charge of monitoring REDD+ } \\
\text { activities. Review, assessment and approval of } \\
\text { REDD+ activities in accordance with socio- } \\
\text { economic development needs. }\end{array}$ \\
\hline
\end{tabular}

Source: Authors, 2018 


\section{DISCUSSIONS AND ANALYSIS}

Initially, we assumed that the management constraints related to the application of REDD+ can be identified at the level of political, institutional and socio-economic factors that influence the functioning of the community forest and consequently the quality of life of the Covimof populations. Certainly, the results showed that the risks of non-application of the REDD+ mechanism are more frequent upstream, at the level of structuring policies, institutions and socioeconomic conditions. They fuel the behavior of stakeholders, justify their interests and access strategies to the community forest, and can cover an entire territory. On the other hand, this hypothesis may contain discrepancies due to the technical component (as opposed to the structural component) of REDD+ implementation. The extent of technical weaknesses that constitute potential REDD+ risks (reference scenario, additionality, leakage, permanence) have not yet been developed in a community space. Thus, REDD+ risks at this level are difficult to manage and the likelihood that communities will be exposed to the vulnerability of REDD+ implementation requirements is high. The response strategy will take the form of control of REDD+ requirements under the UNFCCC.

\section{Reference scenario: mastering the causes of deforestation or mastering socio-economic development trajectories?}

In the majority of REDD+ projects, estimating reductions is the most critical step in the merit of financial offsets. Indeed, Pirard [10] rather requires economic efficiency on the part of the States. This efficiency is proportional to the capacity to define the reference scenario. However, this convergence towards an alleged economic efficiency would depend on the mastery of the type of reference scenario that the country undertakes to operationalize. There are two types of reference scenario. One historical and the other predictive [10]. The first takes into account past considerations. However, it does not specify whether these historically based data can sometimes evolve and undergo changes. Because past causes of degradation may be different from today's causes. The second follows a logic of modelled prediction of socioeconomic development, trying to take into account the evolution of a number of variables that are considered to control the rate of deforestation.

The author believes that a historical scenario can be problematic because it does not take into account transitional forest phenomena. On the other hand, the reliability of predictive scenarios is limited by the changing nature of the explanatory variables, such as the instability of food and agricultural input prices. This may seem rather pessimistic given the various weaknesses noted below. Can we therefore envisage historical reference scenarios that take into account the forest transition or those of a predictive nature where the discounting of variables is obvious?

The answer to this question refers to the ideas of Motel et al., [11], cited by Pirard [10], who lean towards an alternative approach. It is an approach that distinguishes between structural deforestation and deforestation caused by domestic policies. It is not necessarily a nested approach proposed by Nepal in a case of community forestry. Historical reference scenarios do not produce reliable projections of future deforestation for countries with low rates of deforestation (Tchapa, undated). Yet Cameroon has a relatively low deforestation rate of $1.02 \%$ between 1990 and 2000 according to the FAO and is considering via Comifac a historical baseline scenario with an adjustment factor.

In the end, Karsenty et al., 12] were able to define several reference scenario (RS) models. The first set is based on the construction of the RS before the commitment period (strictly historical-based RS, strictly historical-based RS with adjustment factors and predictive RS). The second is based on the ex post determination of the balance sheet and without SR. It is a comparison of the forest stock at the beginning of the period/end of the period with a stock target negotiated at the beginning of the period: this is called the Carbon Stock Mechanism. Taking into account the modifications that may be required over time, it will be preferable to start with a reference scenario that is strictly historically based and that takes into account the principle of forest transition. Methodologies for the reference scenario are still under discussion within the SBSTA [13]. 


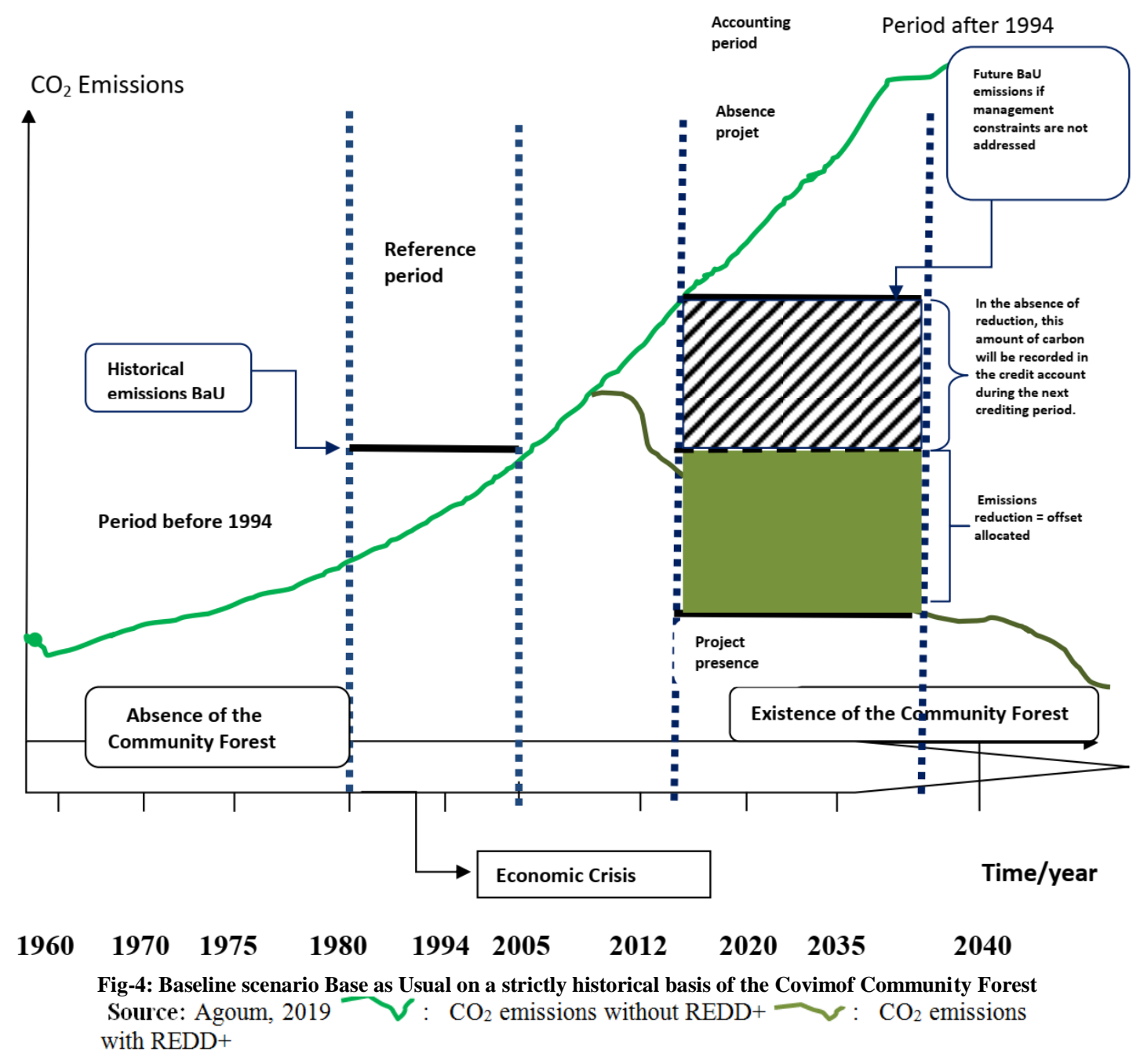

According to the declarations of the Covimof populations, the forest cover was intact before independence. Immediately after independence, a change in the forest cover was observed. In the absence of the community forest, the area was rarely under sale of cuttings. As early as the 1980 s, road infrastructures began to develop. Urban sprawl invaded the urban perishes through migration. Agriculture was lowintensity on fertile land. Logging was more common in forest concessions. For this reason, the reference period is from 1980 to 2005 (see figure above). Within Covimof, carbon emissions increased from 1985 onwards. This was the date when the economic crisis triggered many changes, including structural adjustment, democratization and decentralization that affected the forest. The curve represents the evolution of carbon dioxide $\left(\mathrm{CO}_{2}\right)$ emissions generated by the decrease in forest cover. It has worsened since 1994 , when the government introduced a series of changes in its forestry policy combining change and openness to market mechanisms. Illegal logging has been reinforced by the creation of the Community area where the lack of benefit-sharing has led to uncontrolled access to the resource.

Indeed, most analysts place forest transition theory as the vanguard in determining a reference scenario. This for the majority of countries in the Congo Basin are only at the beginning of their development phase. Forest transition is not a "law of nature" and a number of factors influence its exact course, such as the national context, the economic forces at play and the strategies adopted by the government [14]. When future emissions are above the historical base, there are no offsets. The missed emission reduction is carried forward to the next payment period as a carbon offset. This assumes that management constraints on stakeholders have not been addressed and monitored.

Quality of stakeholders, involvement and types of issues as a risk of Non-additionality [15]

The quality of the stakeholders, their degree of involvement and the type of stakes justify access to the Covimof resource. They constitute vulnerability units related to REDD+ risks. These barriers are related to intrinsic forest management difficulties. In the discussions on the application of the REDD+ process, additionality [16] is presented as the result of a reduction in GHG emissions by the project (project scenario) minus the emissions that would have occurred 
in the absence of the project (baseline) [17]. However, we believe that risks of non-additionality may arise, for example, from the role that forests play as a livelihood substrate and also as a space for divergent appropriation concepts leading to increased deforestation and deforestation.

In addition, these stakeholders need to be aware of the complexity and patience required by, for example, the carbon market. Thus, the education dimension will be relevant to the understanding of REDD. The virtual and non-physical nature and the lack of knowledge of the populations make carbon trading complex [18]. There have not been enough awareness raising and education activities organised for landowners living in villages in Papua New Guinea to inform them. This problem of understanding the REDD system is for Meshack et al., [19] a question of equity, i.e. a form of guarantee that community members understand the notion of REDD+ and the Co-benefits derived from it. "That communities understand the problems that will arise if payments are based on offsetting emissions from industrialised countries and the benefits that will accrue to them if the payments are used to manage community forests". In a Covimof context, the level of education can be a constraint to understanding the REDD mechanism and therefore a real source of vulnerability to REDD+ risks.

\section{Leakage and forest policies: low trend in leakage [20] risk control related to REDD+ activities}

\section{In a mixed approach to REDD+}

implementation, the national phase is for most social forestry managers an anticipation of leakage phenomena insofar as REDD+ action plans must obey national development policies. These guide the behavior of stakeholders. En effet, les migrations internes dus au mariage ont été observées. Girls in most cases leave their families of birth for marriage in a neighbouring village. These different types of migration are reversible. Except in the case of marriage where the young woman will be able to develop her activities elsewhere. Nevertheless, the idea of this work is to highlight the underlying causes of flight. For example, some inhabitants of Covimof own plots of land outside the boundaries of the CF. From North to South, from West to East, there is land belonging to the populations of Akomnyada $1 \& 2$, Faékélé 1 \& 2, Ayos, and Akak. In this way, the deforestation agents near Covimof can continue to develop $\mathrm{CO}_{2}$ emission practices without having to move. Neighbouring villages can even call on those in the Cig for solidarity, clan or family relations. Indeed, the main cause of leakage lies in the conditions of access to forestry land ownership, unregulated logging measures and the instability of agricultural policies.

Moreover, Wunder [21], in a rather particular logic, considers leakage undoubtedly as a "red card" for REDD+. According to this author, leakage can have several origins. First of all, leakage is then more likely when land markets are competitive and integrated at all scales and in all regions. It can also occur when labor and capital are highly mobile, so that activities and emissions displaced by REDD+ will easily flow elsewhere. Taking development concerns into account, the existence of leakage may indeed indicate that the economy is in good health: in response to the barriers put in place by REDD+, production factors move freely in search of new opportunities, keeping the loss of social gains to a minimum. "It is by acknowledging the possible trade-offs between the mitigation objective on the one hand and broader development goals on the other that we may be able to deliberately accept some degree of leakage and reprioritize our mitigation actions. The author presents the different origins of leakage, which in our view can be summarized as a country's sectoral policies and measures. Indeed, as solutions to leakage problems, Wunder [21] advocates, among other things, monitoring, large-scale scaling up and, above all, neutralizing the components related to "alternative lifestyles". Changing lifestyles can be a huge challenge. It is in this sense that Macey et al., [22] assert that "the risk of leakage in REDD+ comes for many from the imbalance of forest policies between countries and the links with the forest products industry and market". The implication is that there are policies and incentives that substantially displace people and goods. These policies can provide a framework for analysing leakage phenomena.

\section{Monitoring as a basis for thinking about the permanence of REDD+ activities}

In general, the approaches proposed to ensure permanence are linked to the effectiveness of carbon credit generation. This is an option apprehended by Dutschke et al., [23] which uses responsibility negotiations to ensure the fungibility of credits: it is the treatment of risks through shared responsibility. The aim is to make developed countries bear a negotiated share of responsibility for the permanence of REDD+ credits once these credits are certified. The developing country will be able to grant preferential access to REDD+credits to a developed country for meeting its obligations if it shares responsibility for nonpermanence. Donor countries being motivated to invest in forest governance. However, no form of regulation of activities has been established, nor the type of REDD+ activity. Is liability or risk management related to sustainable forest management or conservation activities included in REDD+?

Indeed, the shared responsibility approach recommends for the management of responsibilities, the reduction of the risks of non-permanence. These responsibilities are seen as an obligation on the part of donor countries to demonstrate their motivation to fight climate change. Provided that developing countries such as Cameroon can put in place measures to provide additional impetus to the creation of a system to 
regulate mitigation activities. Permanence also includes technical and methodological questions and requirements for the application of the future REDD+ mechanism. It is linked to the period of time that carbon remains in the biosphere. I.e. protected from illegal exploitation, land use changes, conflicts, droughts, bush fires, disease etc. This assumes that mechanisms to guarantee permanence or to ensure the risks of nonpermanence exist, taking into account that the reduction of emissions in the project area is not for eternity. Indeed, Covimof has long been the site of forestry and agricultural activities. It is an agro-forestry strip that has been the centre of interest for several logging companies. Today, the state of the resource highlights the great concern about community reforestation actions.

The systematic coverage of Community Forests should be ensured by reliable control and monitoring actions, providing data on the permanence of Community projects. But this is not the case. The Covimof is managed on a direct labour basis as required by the manual of procedures. Most of the control activities are focused on logging operations in which the administration carries out a kind of remote control; also called the "remote control" of the administration.

Table-5: Ongoing conflicts and resolution mechanism within Covimof

\begin{tabular}{|l|l|l|l|}
\hline $\begin{array}{l}\text { TYPES OF } \\
\text { CONFLICTS }\end{array}$ & CAUSE OR ORIGIN & $\begin{array}{l}\text { RESOLUTION } \\
\text { PROCEDURE }\end{array}$ & OBSERVATION \\
\hline $\begin{array}{l}\text { Dispute between } \\
\text { Covimof and private } \\
\text { operator (economic } \\
\text { partners) }\end{array}$ & $\begin{array}{l}\text { Delayed financial settlements } \\
\text { (receivables) } \\
\text { Non-compliance with } \\
\text { specifications, fraudulent use of } \\
\text { administrative documents. }\end{array}$ & Legal proceedings & $\begin{array}{l}\text { The trees are cut down } \\
\text { and stored at the } \\
\text { various felling sites. } \\
\text { Non-compliance with } \\
\text { contractual obligations. }\end{array}$ \\
\hline $\begin{array}{l}\text { Disputes between } \\
\text { Covimof and the State }\end{array}$ & $\begin{array}{l}\text {-Complex procedure for } \\
\text { withdrawing administrative } \\
\text { documents (renewing waybills, } \\
\text { withdrawing timber removal } \\
\text { authorisations. } \\
\text {-Non-compliance with the simple } \\
\text { management plan or management } \\
\text { agreement. }\end{array}$ & $\begin{array}{l}\text { Forests (Article 136 of the } \\
\text { 1995 Decree and 141(1) of the } \\
\text { - Negotiation article 8(1) of the } \\
\text { Community Forests Procedural } \\
\text { Manual }\end{array}$ & \\
\hline $\begin{array}{l}\text { Litigation between } \\
\text { population and } \\
\begin{array}{l}\text { Covimof management } \\
\text { committee }\end{array}\end{array}$ & $\begin{array}{l}\text {-Absence of socio-economic } \\
\text { achievements (water point, roads, } \\
\text { schools, electricity, etc.). } \\
\text {-Sharing of benefits }\end{array}$ & Unresolved & \\
\hline $\begin{array}{l}\text { Litigation between } \\
\text { Covimof populations }\end{array}$ & $\begin{array}{l}\text {-Non-compliance with parcel } \\
\text { boundaries (land problems) } \\
\text {-People's bad faith }\end{array}$ & $\begin{array}{l}\text {-Amiable } \\
\text {-Recourse to the competent } \\
\text { administration }\end{array}$ & \\
\hline
\end{tabular}

Source: Authors, 2018

In this context, conflicts of several kinds arise, the mode of resolution of which is beyond the control of the stakeholders. The causes of these disputes are of several kinds. The origins vary according to the types of users involved. These conflicts represent segments of vulnerability to climate impact mitigation.

\section{CONCLUSION}

From the outset, REDD+ claims to provide tools to improve the living conditions of these populations (benefits and co-benefits of REDD+ activities). It will only be necessary to ensure that the establishment of the reference scenario and the management of non-additionality, leakage and permanence risks are a priority. In this logic, the initiative taken by the Congo Basin countries through Comifac fundamentally testifies to the firm intention to access the innovative climate change mitigation strategies that REDD+ conveys. Cameroon's ambition is to integrate forest communities in this process. This during this political vision calls for a certain number of concerns for the implementation of REDD+, particularly in the community forestry sector. The Covimof example reflects the different management barriers that are supposed to delay the implementation of avoided deforestation.

Initially, we wondered how Covimof's local management system would be able to allow populations to benefit from the offsets from carbon credits. By admitting that the application of the REDD+ mechanism requires the treatment of management risks, also called technical and methodological constraints that constitute the operating gaps, the objective of this work was to contribute to the identification of management constraints for the implementation of the future REDD+ mechanism (reference scenario, nonadditionality, leakage and non-permanence) in order to develop a socioeconomic, political and institutional framework capable of regulating the implementation of REDD+. 
We have seen that the establishment of a strictly historical reference scenario was necessary because of doubts about the credibility of national data on deforestation and degradation. Moreover, the hypothesis that local communities (Molombo, Okékat, Foakélé, etc.), as well as logging companies, NGOs and the State convey rather contrasting motivations and practices that may hinder the additionality of the REDD+ process was confirmed. On the other hand, policies and measures of any kind, community forest land tenure systems and the necessary land-use planning generate leakage phenomena in the Covimof. In this respect, future sustainable forest management and conservation activities will not be subject to any control. On this basis, permanence will be difficult to manage. Provided that permanence is not only synonymous with assurance and continuity of carbon credits. In the end, the management constraints related to the implementation of REDD+ form a system because they hinder the local development process. We believe that for REDD+ risks to be overcome, a new financial framework to manage REDD+ funds still needs to be designed.

Our work has helped to solve a number of problems that have been solved independently of each other. It has produced clichés that suggest alarmist and pessimistic views on community-based management of forest ecosystems. Our analyses have led to a form of restructuring of REDD+ implementation tools in a social forestry context. As a result, based on the competing behaviors of user actors, a blurred environment was created with forms of land appropriation dictated by poorly assimilated national development policies. As a result, conflict systems were revised downwards. Between ethno-linguistic particularity and the exercise of sovereignty, there is an attachment to forest income. Faced with a "community individualism" that is resistant to any future REDD+ project, a formal and informal competition has been formed related to access to the Covimof.

\section{REFERENCES}

1. Dkamela, G. P. (2011). Le contexte de la REDD+ au Cameroun: causes, agents et institutions. CIFOR.

2. Leménager, T. (2011). The REDD+ mechanism from global to local scale; stakes and conditions of implementation. AFD, Working Paper No. 109, Research Department, ONF International, 85.

3. Threshold at which the drivers of deforestation can be extrapolated from a past period to a future period based on the control of deforestation/degradation drivers.

4. These are factors that take into account the level of development of developing countries in order to avoid as much as possible being held hostage to the development process by the REDD+ mechanism.
5. National circumstances are considered as national data that are intended to corroborate emission factors and activity data. This is the second step in determining a scenario with an adjustment component. The problem at this level is the reliability it provides to the baseline. Most opinions rely on the stages of forest transition. However, it would be wise to analyse a country's societal plans that have a major impact on the future use of forests. Cameroon presents a Growth and Employment Strategy Paper (GESP), a reference framework for government action for the period 2010-2020.

6. This is a period during which data on deforestation drivers and land use maps will need to be obtained.

7. EMN, an independent observatory of forest infractions, is a body in partnership with Minfof for the development of forest law enforcement and regulation strategies. It operates through field activities and records the different infractions related to forest litigation.

8. The RCFI (Reinforcement of Community Forest Management Initiatives) is a project implemented by Minfof under HIPC funds, whose mission is to build the capacities of community forest and provide them with technical and financial support for their forest management initiatives.

9. Fincke, A. (2010). Participation of indigenous peoples and local communities in REDD-plus: challenges and opportunities, indigenous peoples and REDD-plus. IUCN, Forest Conservation Programme. Washington DC 20009 USA, 8.

10. Pirard, R. (2008). Fighting Deforestation (Redd): Economic Implications of Market-Based Financing, IDDRI (Institute for Sustainable Development and International Relations), Ideas for Debate $N^{\circ} 20 /$ Climate Change, 12.

11. Tesch-Römer, C., Motel-Klingebiel, A., \& Tomasik, M. J. (2008). Gender differences in subjective well-being: Comparing societies with respect to gender equality. Social Indicators Research, 85(2), 329-349.

12. Pirard, R., \& Karsenty, A. (2009). Climate change mitigation: should "avoided deforestation" be rewarded?. Journal of Sustainable Forestry, 28(35), 434-455.

13. The formula for the reference case has not yet been established. The extension of the climate regime will now cover the "post-2020" period within the framework of the Durban Platform. The Durban Platform for Enhanced Action sitting in lieu of the SBSTA.

14. Angelsen, A., Brockhaus, M., Kanninen, M., Sills, E., Sunderlin, W. D., \& Wertz-Kanounnikoff, S. (2009). Realising REDD+: National strategy and policy options: CIFOR. Bogor, Indonesia.

15. In general, a project is incremental when the total GHG emissions with the project are less than those that would have occurred in the absence of the 
project. But if the total $\mathrm{CO}_{2}$ emissions with the project are higher than those that would have occurred in a "business as usual" framework, we would rather speak of non-additionality. That is to say that the process of reducing emissions during the project has been hampered by weaknesses or threats.

16. The definition of additionality can be found in Decision 17/CP7 paragraph 43. It derives from the conditions for the application of the CDM.

17. Sathaye, A. S. (2008). U.S. Patent No. 7,392,086. Washington, DC: U.S. Patent and Trademark Office.

18. Paka, T. (2010). The Dream of 'Money from Heaven': How Carbon Trading Schemes Affect the Rights of Indigenous Peoples, in Respecting Rights, Protecting Forests: An Alternative Vision for Reducing Deforestation, A Case Study from the Accra Caucus, 29.

19. Meshack, C. (2010). How to achieve a peoplefriendly REDD process? Lessons from Participatory Forest Management, in Respecting
Rights, Protecting Forests: An Alternative Vision to Reduce Deforestation, Case Study of the Accra Caucus, 23.

20. Any REDD approach should address the complex problems of leakage. They are synonymous with displacement, moving to non-project areas. These areas are located either in the vicinity or outside the department or region where the project is located. Leakage problems are in most cases linked to the displacement of activities from project area A to areas other than A.

21. Wunder, S. (2009). Addressing Leakage, Chapter 7, Advancing REDD: Issues, Options and Impacts, CIFOR, BOGOR, Indonesia, 79-92.

22. Macey, K., Lesolle, D., Hare, B., \& Seburikoko, L. (2009). REDD: The Role of Land Use and Forestry in Mitigation, ECBI (European Capacity Building Initiative) Policy Report.

23. Dutschke, M., \& Angelsen, A. (2008). How do we ensure permanence and assign liability?. Center for International Forestry Research (CIFOR). 